\title{
Architectural and spatial changing of university complexes and buildings in the reformation stage of higher education in Russia
}

\author{
Elena Akhmedova ${ }^{1}$, Anna Zhogoleva ${ }^{2,}{ }^{*}$ and Aleksandra Teryagova ${ }^{2}$ \\ ${ }^{1}$ Samara State Technical University, MolodogvardeyskayaStreet, 194,443001, Samara,Russia
}

\begin{abstract}
The article investigates modern home tendencies of transformation of university complexes. This transformation is based on the carcass of interactions built in the structure of innovative activity and is a prerequisite of the development of the forming university clusters. The main prerequisites of transformations in architectural and spatial environment of universities against the background of the reforms in higher education in Russia are examined. A project experiment grounding the necessity of architectural and spatial changes of university buildings and complexes is described.
\end{abstract}

\section{Introduction}

Changings are inevitable, especially in the time of global changes. Today, in the epoch of "technological outbreak", the understanding that life is going to change globally in one or two decades leads scientific and academic communities to the necessity of quick reaction to these changes. This reaction will allow levelling the negative influences of changes on human way of life in general and functioning of educational environment in particular. The boundaries of usual spheres of activity - scientific, research, educational - are being washed out, processes are merging, interconnecting, mixing, overflowing into each other, the content of these processes is growing old, modernizing itself, converting itself into new forms. The directions of these transformations are outlined in the speech by Vladimir A. Mau at Gaidar Forum in 2017[1]. The Russian Ministry of Education implements reforms in the sphere of creation of new educational standards of higher education (4 generation). Federal Academic Methodological Associations (FAMA) are involved in this work in all directions of study. FAMA in Architecture is not an exception. This facilitates quick innovative reorganization of higher education in Architecture and Civil Engineering in Russia, its orientation to new Professional Standards (PS) of an architect, urbanist, designer and restorer, the fastest flow of young professionals in real practice of innovative design and building. It is as well facilitated by the reorganization of Russian universities, formation of structure of national, innovative and supporting institutions of higher education in the Russian Federation, new conceptions of creation of their architectural and urban planning environment, new university campuses.

*Corresponding author: annazhogoleva@yandex.ru 


\section{Prerequisites of architectural and spatial changings of university buildings and complexes in Russia}

Architectural and spatial changings in real university environment are going in a much slower tempo, however, they are inevitable. Transformation of existing university complexes into "innovative universities" has a row of prerequisites, in different degrees influencing on the further development of academic activity. Here are the main ones of them:

1) Historic process of the development of architecture of university complexes, or evolutionary prerequisites of the environment changing. This is the most natural variant of changings occurring continuously, pacing with the development of society, science and technology. Reorganization, modernization of architectural and urban planning complexes of buildings happens slowly in accordance with the social order, development of this or that scientific field, and sphere of knowledge [2]. Such a slow, phased development may be observed on the example of the old European universities, the history of which goes back to the times of several hundred years ago. Historically the university campuses were and stay the ground for a display of the cutting edge architectural thought. The universities were frequently separated from the state and they developed according to their own laws including the ones of architecture and urban planning. In contrast to the western universities the Russian ones have never had autonomy, were established by the state and were subject to the state authority. Their development depended directly (and continues to do so) on the socioeconomic and internal changes in the country.

2) External factors of university development are the prerequisites of development based on the external interactions creating the impulse for architectural and spatial changings. The main types of interactions, characteristic for modern Russian universities are the following: "university - business", "university - production", "university - authority", "university - city region" [3]. Institutions of higher education currently are striving to become centres of regional innovative development and have every reason for this starting with the educational, human resources base and ending with the territorial and spatial resources. Enumerated interactions lead to the integration of the given potential into innovative research clusters[4]. For modern Russian universities this is the key vector of development in the contemporary stage.

3) Integration processes in the system of higher education are one of the most abstract prerequisites of architectural and spatial development as they are developed directly with the so-called "technological outbreak", the consequences of which are very difficult to predict. Due to the intensive development of new technologies the conventional labour markets are disappearing, some professions come out of demand, and as a consequence necessity of training for some specialties loses significance. In the existing system of education many new processes are integrated, a part of them dies away without reaching its end. The so-called universities of an integrated type - corporate, innovative, project-oriented, network, virtual ones and so on emerge and disappear with the intensity proportional to the development of new technologies. The important direction in the development of the integrated type universities, i.e. penetration into the infosphere, is distinguished most vividly.

It is impossible to deny the fact that regardless of the policy of development of institutions of higher education in Russia a large-scale implementation of new electronic distant educational technologies is being done [5]. Methods of organization of educational process, its monitoring, making decisions about management accept an absolutely new character, happen distantly and consequently require absolutely different, changed architectural and spatial base. Which one? The question stays open. Paradoxically but true is the fact that history of the last decades shows that one may get education, gain success and make a contribution in the development of science and technology without services of traditional universities. Education got at a university acquires a status character, in practice necessary knowledge may be got outside a university as well. For instance, on the site "Machine Education Coursera" one can study the courses of the 
leading USA institutions of higher education - Stanford University, Duke University, University of Michigan, University of Washington, and University of California - for free. After completion of these courses corresponding certificates are given. The fact that the leading revolutionaries of our time in the sphere of technology development (Bill Gates, Steve Jobs, Mark Zuckerberg, John Mackey and some others) neglected the traditional form of higher education acquisition cannot be denied.

The usual architectural and spatial organization of campuses is also changing because of the integration of educational processes in information environment. The necessity of spatial localization of students in one place, living on the territory of campus or nearby is falling away; libraries and educational buildings are changing. For the specialists in the sphere of formation of architectural and urban-planning environment these aspects are the questions of careful study and monitoring.

4) Implementation of actual technologies of ecologization and humanization of educational environment architecture is a prerequisite of organization on the basis of the principles of sustainable development[6]. This means orientation to "green" standards when designing, reconstructing university complexes, particularly when creating the newest objects for scientific research [7]. Ratification of Convention on the Rights of Persons with Disabilities (CRPD) by Russia in 2012 set new objectives before institutions of higher education. These objectives make it necessary for educational institutions to transfer from assistance to people with disabilities to the provision of equal educational opportunities for them. First of all this means that architectural and spatial environment of university buildings must become barrier-free, inclusive[8]. The main theses during its formation are accessibility, safety, informativeness and comfort for mobility impaired users.

\subsection{Prerequisites of formation of the regional centre of innovative development in Samara}

In Russia the process of transformation of the system of existing institutions of higher education in the network of federal universities - centres of innovative regional development began.

Until recently 8 largest state universities founded at the beginning of 20 century were functioningin Samara. Among them were Samara State University (SSU) and Samara State Aerospace University (SSAU), the alliance of which formed Samara University (SU), and Samara State Technical University (SSTU) and Samara State University of Architecture and Civil Engineering (SSUACI) which received the status of a regional flagship university after merging. The consequences of these important changings are a perspective historic objective. However, the administration of the institutions of higher education had to face some current problems which are to be solved currently.

For Samara State Technical University one of the priority development objectives is the formation of a united university campus. Urban planning conditions for location of the educational buildings of two higher schools in the structure of the city give unique opportunities for realisation of this objective: educational buildings are situated in the historic centre of Samara city, are integrated in the urban tissue, stretch along MolodogvardeyskayaStreet. This street is an important axis of the central part of the city; the major urban-planning ensemble of Samara centre situated between the educational buildings of SSTU and SSUACI - boulevard on PolevayaStreet, Square of Glory, Samara Square, Kuybyshev Square - boarders with Molodogvardeyskaya Street.

Regional authorities announce the objective of design of an open innovative university complex "Open university" - as well. For this purpose the government of Samara Oblast reserved the territories near the ground on which a football stadium meant for hosting the 2018 FIFA World Cup is being erected. Without any doubt if this ground is regarded in the structure of Samara-Togliatti agglomeration, it is going to take almost the central place [2]. However, if 
its dislocation is studied with regard to the existing scientific and research university base of Samara, it becomes clear that it is situated on the peripheral territory in the city, so it is unlikely that it can become a place of attraction for student scientific activity in the short run; it is a perspective of future. That is why at the same time with the politics of regional authorities in the sphere of innovative research activity, institutions of higher education are organizing campus student environment of already existing buildings, constructions and grounds reorganizing it so that it corresponds with the modern tendencies of science and education.

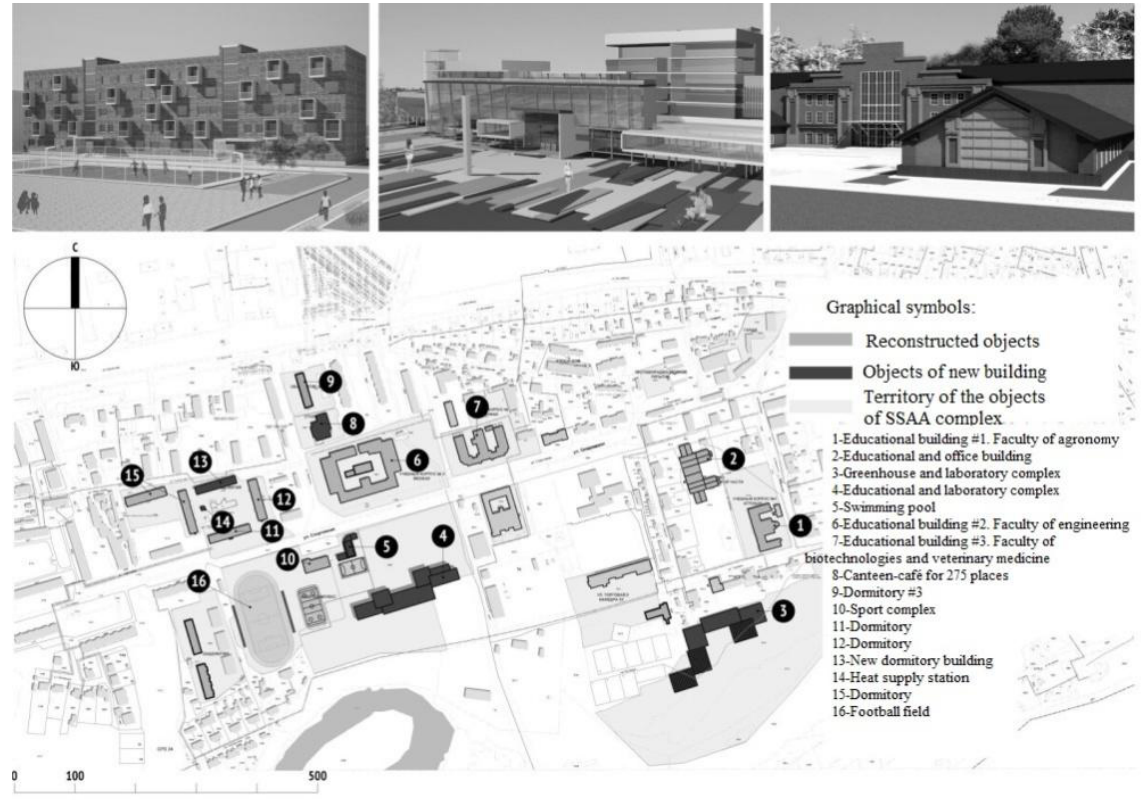

Fig.1. Development project of Samara State Agricultural Academy (SSAA)

For example, working out the programme of development of its higher school Samara State Agricultural Academy (SSAA) (the largest one in Volga Region (Povolzhye)) turned to outsources for the design of the concept of architectural and spatial development of its territories and complexes (fig.1). The design was made at the Faculty of architecture of SSUACI in the boundaries of a scientific research by the forces of master students and research workers (associate professor Zhogoleva, master students Maltseva and Navas).

\section{Experiment in environmental changing of the flagship university}

For the purposes of realization of the programme of flagship university of Samara Region SSTU has to study the conditions and prerequisites of architectural and urban-planning development and design of the university complex environment. At present time educational activity is being carried in more than 10 educational buildings. Educational building \#7 of SSTU became the ground for the project experiment. This educational building is situated in the central part of Samara City, is included in the main complex of university, and is placed on the boarders of the following streets: Lesnaya, Pervomaiskaya, Molodogvardeyskaya and Polevaya.

The building consists of three educational buildings one of which is not supposed for reconstruction. Educational buildings are placed on a composite topography and ground elevation changes in its various parts are more than 1 floor (fig.2.). The main entrance in the building is organized in the central building, large hall with two tiers of windows of which is of little use nowadays and generally functions for communication. 
The existing building, unfortunately, not to full extent answers modern requirements of contemporary educational establishments.

Necessary fundamental elements such as cloakroom is absent, students' public catering is not organized. The building does not fit for the presence of population groups with low mobility. The effectiveness of usage of the grounds is low. The time slot of students' presence in the educational building is limited by the hours of studies.
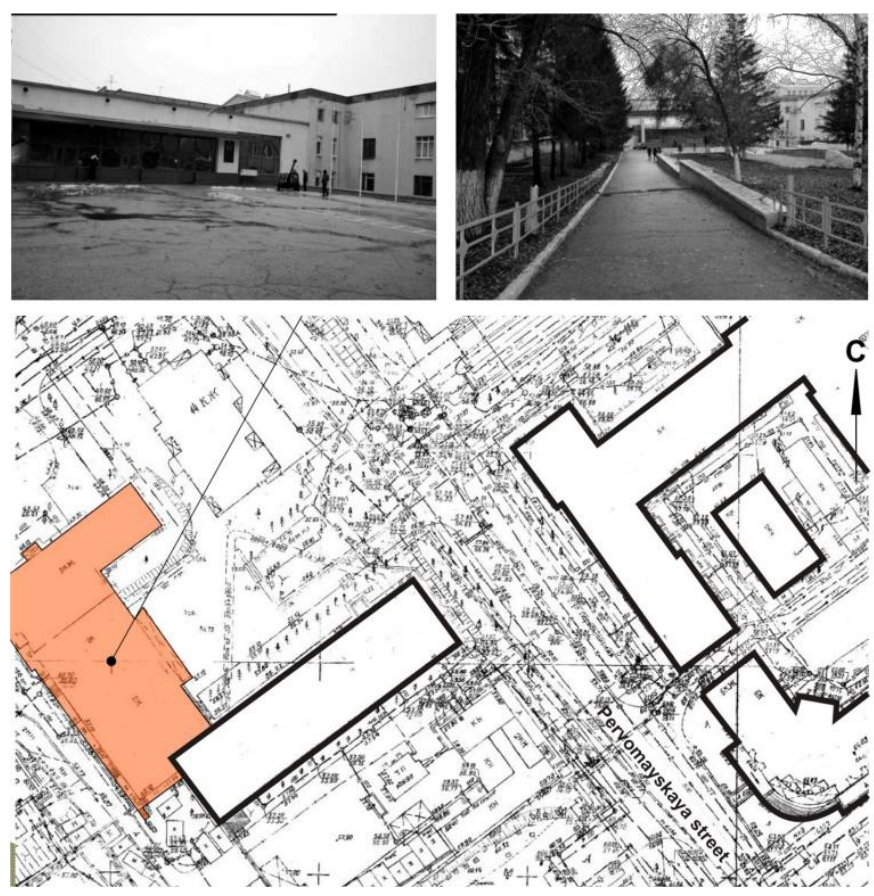

Fig.2. Current condition of SSTU educational building

It was necessary for the students and lecturers of the Faculty of architecture of the united university to create modern academic and working environment in which students and lecturers could study, work, develop their scientific thoughts and implement them into practice.

\subsection{Formation of the functional programme}

Preproject research consisted of several stages:

1)Analysis of urban-planning situation. The remoteness of the educational building from the main university complex, its possible inclusion in the structure of the future campus was studied. The examination of urban-planning reserves was done with the purpose of finding possibilities of widening, easements of appertaining development, buffer and sanitaryprotection zones of networks were analysed.

2) Stage of examination of the buildings. All the floors (including the basement and apparatus ones) were examined. Measurements were taken, corresponding planning was studied, and monitoring of changes was done in relation to the first project decision and its planning and functional transformations. Photofixation of the premises and main constructions was done.

3) Stage of the development of functional programme. This stage was of the greatest interest because the main executors of project decisions were the students of the Faculty of architecture, ACEI, SSTU, and they were the target consumer audience of this reconstruction project. In 
essence they projected the building for themselves. In our opinion, the process of the development of functional programme of the educational building reconstruction could be defined as work according to the method of "participation", when a group of interested people is included in the staff of the project group [5].

In this case the work done by the students can be evaluated as a detailed sociological research as a result of which suggestions on functions, amount and size of the premiseswere formed. Screening and analysis of these data allowed creating functional programme of the project.

\subsection{Project}

Design was done in two directions.

One of them supposed minimal interference in the existing structural scheme of buildings. At the same time functionality was supposed to change quite substantially. From the educational building with exclusively educational premises the space of buildings was suggested to transform into a multifunctional space with the opportunities of holding extracurricular events - conferences, master classes, exhibitions. The important part of the design decision became the design of co-working spaces. The authors suggested saturating the environment with the accompanying functions (public catering, cloakroom, service printing centres, etc.).

The second more developed programme is the concept of a large-scale reconstruction of the educational building with the bulkhead of additional floors above the already existing ones and the reconstruction of the facades. The average one-floor with two tiers of windows volume of educational building is suggested to complete with the second two-level floor with the possible exit to the accessible roof area which can be used as a working area in the warm season. The right three-floor volume of educational building is suggested to be supplemented with one floor; the existing apparatus floor is to be reconstructed into the exploited one and a new apparatus floor is to be made above the new erected floor.

Besides the spaces enumerated for the first variant, it was suggested to create hostel premises in the bulkhead above the three-storeyed educational building for student groups and lecturers coming to different events. Speaking about the planning of interior spaces it should be mentioned that working areas have a free layout, the majority of dividing walls are relocatable partitions, so the spaces can be reconstructed quickly and comfortably in accordance with the events held there.

In both cases it was supposed to divide the hall in the central volume of educational building into two levels. Due to the fact that interior spaces of the first floor have height differences floor elevations change in the building, the project suggests supplementing the existing communications with lifts and elevators for unimpeded movement and provision of accessibility in accordance with the requirements of "universal design".

Besides the reconstruction of the educational building itself a suggestion was made about the improvement of surroundings - garden square and working area in the open air. Here benches and pavilions, exhibition and information boards, planting of trees and shrubs are foreseen. The square is united with the educational building by a spacious paved ground with the de-mountable exhibition units. It should be mentioned that the work over the project was carried by small project groups of 2-4 students under the leadership of two curators. This allowed sharing the responsibility for the design of different function units and developing not only the principle scheme but the interior decisions as well and also suggestions on the changing of the exterior outlook of the building. 


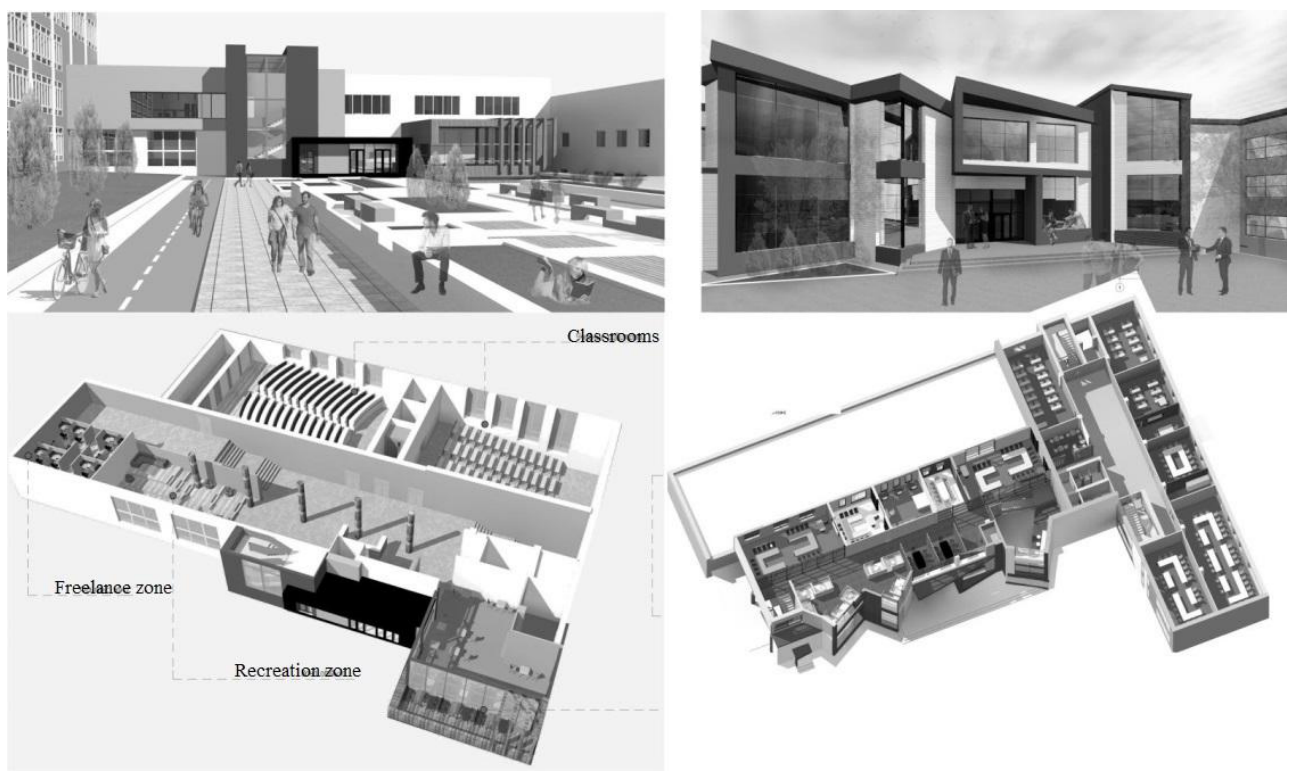

Fig.3. Options of reconstruction of SSTU educational building

\subsection{Designer - customer interaction}

The experimental project activity received its consecutive continuation in the presentation of the projects to the administration of the flagship university by the designers who defended, reported and disputed about campus development, perspectives of its architectural and urban-planning formation. As a result a row of suggestions emerged. It was about the implementation of new campus spaces and grounds in the city environment. These actions could lead to the assemblage of the city and university environments, give an impulse for the more productive work, provide the concentration of scientific, research and creative potential of the city on the basis of the united university campus.

\section{Conclusion}

University complexes have always had an important city-forming significance. Development of the regional innovative research potential is possible on the basis of modernization of higher educational institutions in symbiosis with production, business and authority. Hence formation of the new environment of university campuses is a step on the way to creation of innovative scientific and research clusters of large cities and agglomerations[9].

\section{References}

1. URL: http://gaidarforum.ru/news/eksperty-gaydarovskogo-foruma-peresmotreliparadigmu-vysshego-obrazovaniya/.

2. G. P. Trencher, M.Yarime, A. Kharrazi, Journal of Cleaner Production50, 40-55 (2013).

3. A.V. Zhogoleva, A.N. Teryagova,Scientific review9, 362-365 (2015).

4. A.Beynaghi, G. Trencher, F. Moztarzadeh, M. Mozafari, W. L.Filho, Journal of Cleaner Production 112(4), 3464-3478 (2016). 
5. A.V.Zhogoleva, E.A. Drachkova,Architecturaland Urban Planning Transformation of University Campuses(2014).

6. T.Ya. Vavilova, D.S. Kayasova, Vestnik SGASU. Town Planning and Architecture 2, 7984 (2016).

7. A. I. Amr, Sh. Kamel, G. El Gohary, J.Hamhaber, Procedia - Social and Behavioral Sciences 216, 181-193 (2016).

8. Rebecca Croog, Geoforum 74, 108-116 (2016).

9. Y.Stukalina, Procedia - Social and Behavioral Sciences235, 12-21 (2016). 